\title{
Investigation of the health effects on workers exposed to respirable crystalline silica during outdoor and underground construction projects
}

\author{
DIMITRIOS KERAMYDAS ${ }^{1}$, PETROS BAKAKOS ${ }^{2 *}$, MANOS ALCHANATIS ${ }^{2}$, \\ PETROS PAPALEXIS $^{1}$, IOANNIS KONSTANTAKOPOULOS ${ }^{3}$, KYRIAKI TAVERNARAKI ${ }^{4}$, \\ VASILEIOS DRACOPOULOS ${ }^{5}$, ANTONIOS PAPADAKIS ${ }^{6}$, EUGENIA PANTAZI ${ }^{7}$, GEORGIOS CHELIDONIS ${ }^{8}$, \\ ELIAS CHAIDOUTIS ${ }^{9}$, THEODOROS C. CONSTANTINIDIS ${ }^{10}$, CHRISTINA TSITSIMPIKOU ${ }^{11}$, \\ NIKOLAOS KAVANTZAS ${ }^{1}$, EFSTRATIOS PATSOURIS ${ }^{1}$, KONSTANTINOS TSAROUHAS ${ }^{12^{*}}$, \\ DEMETRIOS A. SPANDIDOS ${ }^{13}$ and ANDREAS Ch. LAZARIS ${ }^{1}$ \\ ${ }^{1}$ 1st Department of Pathology, School of Medicine; ${ }^{2} 1$ st Department of Pneumonology, Medical School, \\ National and Kapodistrian University of Athens, 11527 Athens; ${ }^{3}$ Ministry of Labor and Social Affairs, \\ National Focal Point of the European Agency for Safety and Health at Work (EU-OSHA), 10110 Athens; \\ ${ }^{4}$ Department of Imaging and Interventional Radiology, 'Sotiria' Hospital, 11527 Athens; ${ }^{5}$ Hellenic Institute for \\ Occupational Health and Safety (ELINYAE), 10445 Athens; ${ }^{6}$ Directorate of Public Health, Region of Crete, \\ 71201 Heraklion; ${ }^{7}$ Department of Hygiene, Epidemiology and Medical Statistics, Medical School, National and \\ Kapodistrian University of Athens, 15772 Athens; ${ }^{8}$ National Actuarial Authority, 10559 Athens \\ ${ }^{9}$ Ministry of Interior, 10563 Athens; ${ }^{10}$ Laboratory of Hygiene and Environmental Protection, \\ Democritus University of Thrace, School of Health Sciences, Faculty of Medicine, 68100 Alexandroupolis; \\ ${ }^{11}$ General Chemical State Laboratory of Greece, 11521 Athens; ${ }^{12}$ Cardiology Department, \\ University General Hospital of Larissa, 41110 Larissa; ${ }^{13}$ Laboratory of Clinical Virology, \\ School of Medicine, University of Crete, 71003 Heraklion, Greece
}

Received April 27, 2020; Accepted May 25, 2020

DOI: $10.3892 / \mathrm{etm} .2020 .8786$

Correspondence to: Dr Petros Papalexis or Dr Andreas Ch. Lazaris, 1st Department of Pathology, School of Medicine, National and Kapodistrian University of Athens, 75 Mikras Asias road, 11527 Athens, Greece

E-mail: petranpapalex@gmail.com

E-mail: alazaris@med.uoa.gr

${ }^{*}$ Contributed equally

Abbreviations: $\mathrm{SiO}_{2}$, Silicon dioxide - crystalline silica; RCS, respirable crystalline silica; COPD, chronic obstructive pulmonary disease; XRD, X-ray diffraction; FTIR, fourier transform infrared spectroscopy; $\mathrm{KBr}$, potassium bromide; PFTs, pulmonary function tests; FEV1, forced expiratory volume in one second; FVC, forced vital capacity; $\mathrm{FEF}_{25-75}$, the mean forced expiratory flow between the 25 and $75 \%$ of the FVC; TLC, total lung capacity; $\mathrm{DL}_{\mathrm{CO}}$, diffusing capacity or transfer factor $\left(\mathrm{TL}_{\mathrm{CO}}\right)$ for carbon monoxide; $\mathrm{K}_{\mathrm{CO}}$ $\left(\mathrm{DL}_{\mathrm{CO}} / \mathrm{VA}\right)$, carbon monoxide transfer coefficient (diffusing capacity for carbon monoxide adjusted for alveolar ventilation) (carbon monoxide transfer coefficient is approximately $\mathrm{K}_{\mathrm{CO}}$ /barometric pressure in $\mathrm{ml} / \mathrm{min} / \mathrm{mmHg} / \mathrm{l}$ ); HRCT, high resolution computed tomography

Key words: silicosis, $\mathrm{SiO}_{2}$, construction workers, occupational exposure, occupational exposure limit, occupational health
Abstract. Chronic exposure of workers to powder containing crystalline silica (Silicon dioxide; $\mathrm{SiO}_{2}$ ) can lead to chronic lung diseases (lung cancer, silicosis, etc.). Aim of this study was to evaluate the exposure of Greek construction workers to $\mathrm{SiO}_{2}$ and describe their pulmonary function. The study involved 86 outdoor and underground workers. Medical and professional history was obtained, and breath samples were collected at morning hours through a mask for the determination of $\mathrm{SiO}_{2}$ levels. Pulmonary function tests, radiological examination and evaluation of radiographs were also performed. Pulmonary function examination showed that the majority of the workers were within normal range $(61.4 \%)$ while the rest were diagnosed with mild (26.5\%) and more severe impairment (7.24\%). Working conditions (underground-outdoor) were statistically significantly related to the categorization of pulmonary function $(\mathrm{P}=0.038)$. During radiological examination, the type of working activity/ conditions (underground-outdoor) were statistically significantly related to the categorization of these findings $(\mathrm{P}=0.044)$. Of the 69 employees, 52 did not present findings (75.4\%) and 5 were diagnosed with findings specific to occupational diseases (7.23\%). Environmental exposure to respirable crystalline silica (RCS) was detected at $0.0125 \mathrm{mg} / \mathrm{m}^{3}$ in the workplace, which is not beyond the legal limits. Underground workers with more than 15 years of exposure to $\mathrm{SiO}_{2}$ are more likely to present chronic silicosis compared to the workers of outdoor activities. 


\section{Introduction}

The working environment of industries in the construction branch, both in underground and in outdoor activities, is by its nature burdened with particulate dust $(1,2)$. This dust, either inert or with inherent toxic properties, along with other chemicals that exist in the working environments, constitute a threat to the health and safety of workers, since chronic exposure can lead to serious respiratory diseases and even systemic disorders (3-5). In particular, when the dust contains free crystalline silicon dioxide (silica, $\mathrm{SiO}_{2}$ ) special measures and precautions are required since once inhaled, the dust ceases to be inert and can cause chronic lung diseases such as silicosis, chronic obstructive pulmonary disease (COPD; emphysema) and lung cancer $(1,2,6)$.

Silicon dioxide is the second most abundant element (following oxygen) in the earth's crust, is a group IV metal oxide that occurs in nature in three 3 forms: crystalline, microcrystalline (or cryptocrystalline) and amorphous (non-crystalline) (7). The term 'crystalline' that is commonly used refers to the orientation of silicon molecules $\left(\mathrm{SiO}_{2}\right)$ in a fixed configuration against a non-periodic, random molecular arrangement, designated as amorphous. The three most common crystalline forms (3 main polymorphs) of silicon that occur in the working environment are quartz, cristobalite and tridymite $(2,8,9)$. Quartz is the second most common mineral in the world (8).

Inhalation of respirable crystalline silica (RCS) can lead to serious health effects, such as silicosis, COPD, tuberculosis and lung cancer (10-14). Respiratory diseases often occur in construction workers operating in underground excavation and tunneling constructions (15-17), as well as in outdoor ones (18). Studies have shown that the potential exposure of construction workers to RCS exceeds that of 3 million in the European Union, 1.7 million in the US and 350,000 in Canada (6).

Silicosis is a type of pneumoconiosis caused by exposure of workers to inhaled crystalline silica powder (19). Crystalline silicon dioxide, in the form of quartz powder or 'cristobalite' and tridymite, is responsible for causing silicosis that is categorized as an occupational disease $(10,11)$. It is characterized by the appearance of pulmonary fibrosis and silica nodules. The development - progression of the disease continues even after the interruption of the exposure $(15,16)$. There are 3 forms of the disease: Chronic, acute and lightning stroke. The latter occurs after massive exposure to silica dust. It presents with shortness of breath, fever, cough and weight loss and soon progresses to respiratory failure not responding to corticosteroids $(20,21)$.

Cancer is the first cause of work-related deaths in the EU (9). The International Cancer Research Organization (IARC) stated in its 100C monograph that 'silica or inhalation of quartz or cristobalite powder is carcinogenic to humans (Group 1 of carcinogens for humans)' $(15,17,22)$.

The European Union Scientific Committee on Occupational Exposure Limits (SCOEL) has assessed the impact of crystalline silica (respiratory dust) on employee health, and has proposed a limit value of $0.1 \mathrm{mg} / \mathrm{m}^{3}$ which would mean avoiding 99,000 cancer cases by 2069 with total health benefits valued at between 34 billion and 89 billion euros (9). The above proposal by SCOEL has led to the adoption of the
European Union Directive 2017/2398 L 345/87 that aims at improving the prevention of occupational cancer cases that can be avoided (9).

Given the nature of the materials used in the construction industry, the powder may contain significant amounts of $\mathrm{SiO}_{2}(1,18,23)$. According to the International Labor Organization (ILO), silicosis, an incurable disease, requires quantitative and qualitative control of respiratory crystalline silica and the development of appropriate control measures (24).

The importance of the current study is based on the fact that we need to take under consideration the high occupational exposure to airborne powders of people working at underground and outdoor construction, drilling, concrete launching and machinery movement together with the absence of relevant studies in Greece. The purpose of the study herein was to evaluate the exposure of workers to respiratory crystalline silica $\left(\mathrm{SiO}_{2}\right)$ and examine the condition of workers' pulmonary function.

\section{Materials and methods}

Patients. The study involved 59 employees from one construction company mainly engaged in outdoor construction and 27 employees from a second construction company working exclusively at underground projects with their main activity being tunneling. A total of 86 employees participated all of whom, suffered from active exposure to inhalable crystalline silicon dioxide. The construction workers who participated were categorized as artisans - builders, machine operators, builders - contractors, blasters, electricians, sorting and packaging workers. The clinical/epidemiological history included both the medical and the professional one, in order to determine the relationship between exposure to a substance and the development of respiratory disease. The relevant information included the aggravating factors, the appearance and progression of the disease, the family and medical history of each exposed worker. Other medical allergic or respiratory disorders in childhood were also reported in the medical history together with the smoking habits of each participant (25). Certain characteristics (height, weight, age, years of work) of the exposed workers were recorded.

Environmental measurements. In the present study samplings took place during the year of 2015. To test for dust at the workplace (solid particles or mixtures suspended in the air), environmental measurements - samplings were performed to ensure compliance with national and European legislation on industrial hygiene. In the above measurements, the sampling time corresponded to at least 4 hours and the analysis technique for determining the content of $\mathrm{SiO}_{2}$ (mainly quartz and cristobalite) was carried out by various methods such as X-ray diffraction (XRD), NMAM 7500 method, or by infrared spectroscopy via Fourier (Fourier Transform Infrared Spectroscopy) NIOSH 7602, or by visible VIS spectroscopy with the NIOSH 7601 method $(1,25)$. According to the National legislation for the protection of workers from natural, chemical and biological factors, when there is a group of workers who perform the same or similar tasks in the same place and under the same conditions, in a way that they can 
reasonably be considered to be subjected to approximately the same degree of exposure to this particular chemical agent, in that case the testing may take place in groups and in a way that gives representative results. In our work, an individual testing was performed on 1 for every 10 employees in the same job. In particular, individual sampling was performed on 3 employees in a total of 27 in the underground construction projects where the sampling equipment was placed (26). We followed the method of Fourier transform infrared spectroscopy (FTIR) that uses 3 sampling filters in underground projects in order to calculate the individual exposure of respiratory $\mathrm{SiO}_{2}$ in workers. A breathing zone was considered as an imaginary hemisphere with a radius of $30 \mathrm{~cm}$ extending in front of the employee's face and centered on the middle of the imaginary line connecting his ears. Sampling was performed on workers in workplaces with high exposure to dust and on sprayed concrete operators, builders, machine operators, engineers, blasters and material sorters. The sampling time was $8 \mathrm{~h}$ for each sample taken. During the period of the environmental tests and of the individual sampling from underground workers at all jobs, a high accumulation of dust was recorded because of the use of GUNITE spray concrete. This concrete contains chemical agents such as sodium silicate $\left(\mathrm{Na}_{2} \mathrm{SiO}_{3}\right.$; chemical compound with cement that dries it immediately). In cases where cement contains $>2 \%$ of quartz, workers are likely to present radiological findings of silicification several years after exposure (27). Individual sampling was performed with a SKC 224-PCTX Respiratory Dust Sampling Pump (SKC Inc.). The device is intended for the detection and measurement of particles (inert dust, toxic dust, etc.) in the work environment. The above device is a pump with a flow rate of $750-4,000 \mathrm{ml} / \mathrm{min}$ with a built-in battery. Samples were collected on a filter which was weighed before and after sampling and analyzed for the detection of crystalline silica. For the current samplings, a Dorr Oliver type head with a flow of $2 \mathrm{l} / \mathrm{min}$ was used to collect samples of 960 liters of air each, on a $37 \mathrm{~mm}$ cellulose ester filter. Flow was checked before and after sampling. The analysis procedure using the IR technique follows these steps: a known amount of 1,3-butanediol was added at the sampling filter on which the powder was collected and incubation at $600^{\circ} \mathrm{C}$ followed. The residue was then mixed with a given amount of potassium bromide $(\mathrm{KBr})$, triturated and homogenized in a vibrating mill. Part of this mixture was used to produce a $\mathrm{KBr}$ tablet, which was placed as a cell in the infrared spectroscope. Absorption was performed on an FTIR spectrometer (model WQF-510A) at wavelengths $779 / 798 \mathrm{~cm}^{-1}$ to identify and quantify quartz.

Lung function. Pulmonary function tests (PFTs) in our study were performed at the 1st Academic Department of Pneumonology of the General Hospital of Thoracic Diseases of Athens 'Sotiria' using a spirometer (Cosmed, Quark PFT Pulmonary Function Testing and Sensor Medics ${ }^{\mathrm{TM}}$ Erich Jaeger). PFT results were categorized as within normal limits, mild obstructive syndrome, mild decrease in diffusion capacity, small airway dysfunction, moderate restrictive syndrome, and upper thoracic airway dysfunction.

PFTs were performed using a commercially available system (Master Screen, Erich Jaeger GmbH, Wuerzburg, Germany). Forced expiratory volume in one second (FEV1), forced vital capacity (FVC), FEV1/FVC ratio, the mean Forced Expiratory Flow between the 25 and $75 \%$ of the FVC $\left(\mathrm{FEF}_{25-75}\right)$, total pulmonary capacity (TLC) - total lung capacity, diffusing capacity or transfer factor $\left(\mathrm{TL}_{\mathrm{CO}}\right)$ for carbon monoxide $\left(\mathrm{DL}_{\mathrm{CO}}\right)$, and the carbon monoxide transfer coefficient (diffusing capacity for carbon monoxide adjusted for alveolar ventilation) $\left[\mathrm{K}_{\mathrm{CO}}\left(\mathrm{DL}_{\mathrm{CO}} / \mathrm{VA}\right)\right]$ were recorded. Post-bronchodilator values were obtained $20 \mathrm{~min}$ after the administration of $400 \mathrm{mg}$ salbutamol via a spacer (100 mg x 4 puffs). $\mathrm{DL}_{\mathrm{CO}}$ and diffusing capacity for carbon monoxide adjusted for alveolar volume $\left(\mathrm{DL}_{\mathrm{CO}} / \mathrm{VA}\right)$ were assessed by means of the single breath method with the patient in the sitting position (28). Lung function measurements were expressed as percentages of predicted values (20). The results were interpreted in accordance with the guidelines of the American Thoracic Society (29-31).

Moderate restrictive pulmonary syndrome was defined as patients presenting TLC ranging from 60 to $79 \%$ of the predictive values, small airway dysfunction was defined as patients presenting $\mathrm{FEF}_{25-75}$ less than $65 \%$ of the predictive values with FVC and FEV1 $>80 \%$ of the predictive values, mild decrease in diffusion capacity was defined as patients presenting DLCO ranging from 60 to $79 \%$ of the predictive values and mild obstructive was defined as patients presenting $\mathrm{FEV} 1 / \mathrm{FVC}<75 \%$ and $\mathrm{FEV} 1>80 \%$ of the predictive values.

Radiological findings. The chest X-rays of the participants were performed at the Department of Imaging and Interventional Radiology of the above-mentioned hospital; the Siemens X-RAY Diagnostics Axiom Vertix Solitaire M radiograph was used. To perform the chest high resolution computed tomography (HRCT), the INGENUITY CORE 64 system $\left(\right.$ PHILIPS $^{\circledR}$ ) was used. The radiographs were evaluated according to the system developed by the International Labor Office Classification System in $1980(32,33)$.

Statistical analysis. Statistical analysis was performed with IBM-SPSS v.21 (IBM Corp.). The level of statistical significance was set at $5 \%(\mathrm{P}=0.05)$. The detection of any possible correlation between the type of construction and the radiological findings was performed using Pearson's $\chi^{2}$ test.

Ethical approval. This research was approved by the bioethics and ethics committee of the Medical School of the National and Kapodistrian University of Athens under the decision 6323 received on the 6th March 2013. Written consent was obtained from each employee who participated in the study.

\section{Results}

All workers belonged to the same socioeconomic class, with an average age of 41.04 years [standard deviation (SD): 9.68] and an average of 15.69 years of work (SD: 10.30); 70 employees were former and current smokers and did not use prescription drugs. In more detail, underground construction workers had an average age of 41.26 years (SD: 9.67) and an average of 18.70 (SD: 11.32) working years. Outdoor construction workers had an average age of 40.93 years (SD: 9.76) and an average of 14.31 (SD: 9.59) working years. 
Table I. Environmental testing of employees working in underground construction projects.

\begin{tabular}{|c|c|c|c|c|}
\hline Job position & Dust quantity (mg) & $\begin{array}{l}\text { Quantity of } \mathrm{SiO}_{2} \\
\text { at the filter }(\mu \mathrm{g})\end{array}$ & $\begin{array}{l}\text { Quantity of } \mathrm{SiO}_{2} \\
\text { in the air }\left(\mathrm{mg} / \mathrm{m}^{3}\right)\end{array}$ & $\begin{array}{l}\text { Limit according to } \\
\text { the EU } 2398 / 2017\end{array}$ \\
\hline GUNITE launcher concrete operator & 2.59 & 12 & 0.0125 & $0.1 \mathrm{mg} / \mathrm{m}^{3}$ \\
\hline Craftsman builder & 4.50 & 12 & 0.0125 & $0.1 \mathrm{mg} / \mathrm{m}^{3}$ \\
\hline Machine operator & 4.70 & 12 & 0.0125 & $0.1 \mathrm{mg} / \mathrm{m}^{3}$ \\
\hline
\end{tabular}

Table II. Pulmonary function test results.

\begin{tabular}{|c|c|c|c|c|c|c|}
\hline \multirow[b]{2}{*}{ Test } & \multicolumn{2}{|c|}{ Average values $\pm \mathrm{SD}$} & \multirow[b]{2}{*}{ Characterization } & \multirow[b]{2}{*}{ Frequency } & \multirow[b]{2}{*}{$\%$} & \multirow[b]{2}{*}{ Normal values } \\
\hline & Pre values & Post values & & & & \\
\hline FVC \% PRED (liters; n=82) & $\begin{array}{r}73.0 \pm 3.74 \\
107 \pm 12.1\end{array}$ & $\begin{array}{r}71.5 \pm 2.50 \\
106 \pm 11.9\end{array}$ & $\begin{array}{l}\text { Not normal } \\
\text { Normal }\end{array}$ & $\begin{array}{r}3 \\
79\end{array}$ & $\begin{array}{l}3.74 \\
96.3\end{array}$ & $80-120 \%$ \\
\hline FEV1\% PRED (liters; n=82) & $\begin{array}{r}75.8 \pm 1.48 \\
101 \pm 11.1\end{array}$ & $\begin{array}{r}85.5 \pm 10.9 \\
103 \pm 15.7\end{array}$ & $\begin{array}{l}\text { Not normal } \\
\text { Normal }\end{array}$ & $\begin{array}{r}4 \\
78\end{array}$ & $\begin{array}{r}4.9 \\
95.1\end{array}$ & $80-120 \%$ \\
\hline FEV1/FVC $(n=81)$ & $\begin{array}{l}68.8 \pm 5.24 \\
97.7 \pm 11.5\end{array}$ & $\begin{array}{l}71.7 \pm 5.00 \\
94.4 \pm 15.7\end{array}$ & $\begin{array}{l}\text { Not normal } \\
\text { Normal }\end{array}$ & $\begin{array}{r}6 \\
75\end{array}$ & $\begin{array}{l}7.44 \\
92.6\end{array}$ & $\begin{array}{l}>75 \text { (in normal } \\
\text { patients or } \\
\text { patients with } \\
\text { moderate } \\
\text { restrictive } \\
\text { syndrome) }\end{array}$ \\
\hline $\mathrm{FEF}_{25-75 \%}$ PRED (1/sec; n=82) & $\begin{array}{l}52.9 \pm 9.17 \\
86.4 \pm 20.6\end{array}$ & $\begin{array}{l}65.2 \pm 8.56 \\
97.9 \pm 21.1\end{array}$ & $\begin{array}{l}\text { Not normal } \\
\text { Normal }\end{array}$ & $\begin{array}{r}9 \\
73\end{array}$ & $\begin{array}{l}11.0 \\
89.0\end{array}$ & $65-135 \%$ \\
\hline TLC \% PRED (n=83) & $\begin{array}{r}67.9 \\
100\end{array}$ & $\begin{array}{l}11.8 \\
10.3\end{array}$ & $\begin{array}{l}\text { Not normal } \\
\text { Normal }\end{array}$ & $\begin{array}{r}8 \\
75\end{array}$ & $\begin{array}{l}9.63 \\
90.4\end{array}$ & $80-120 \%$ \\
\hline $\begin{array}{l}\mathrm{DL}_{\mathrm{CO}}(\mathrm{mmol} / \mathrm{kPa} \cdot \mathrm{min}) \\
\% \operatorname{PRED}(\mathrm{n}=84)\end{array}$ & $\begin{array}{r}71.0 \pm 4.3 \\
96.2\end{array}$ & $\begin{array}{l}138 \pm 10.9 \\
11.5\end{array}$ & $\begin{array}{l}\text { Not normal } \\
\text { Normal }\end{array}$ & $\begin{array}{r}9 \\
75\end{array}$ & $\begin{array}{l}10.7 \\
89.3\end{array}$ & $80-120 \%$ \\
\hline $\mathrm{K}_{\mathrm{CO}}\left(\mathrm{DL}_{\mathrm{CO}} / \mathrm{VA}\right) \% \operatorname{PRED}(\mathrm{n}=84)$ & $\begin{array}{l}136 \\
105\end{array}$ & $\begin{array}{l}9.34 \\
33.2\end{array}$ & $\begin{array}{l}\text { Not normal } \\
\text { Normal }\end{array}$ & $\begin{array}{r}2 \\
82\end{array}$ & $\begin{array}{l}2.42 \\
97.6\end{array}$ & $80-120 \%$ \\
\hline
\end{tabular}

Lung function measurements were expressed as percentages of predicted values except FEV1/FVC (17). Post Bronchodilation values were obtained $20 \mathrm{~min}$ after inhalation of 4 puffs of salbutamol (total inhaled concentration for each participant: $400 \mu \mathrm{g}$ ). FEV1, forced expiratory volume in the 1st second; FVC, forced vital capacity; $\mathrm{FEF}_{25-75}$, the mean forced expiratory flow between the 25 and $75 \%$ of the FVC; TLC, total lung capacity; DLCO, diffusing capacity for carbon monoxide; $\mathrm{K}_{\mathrm{CO}}\left(\mathrm{DL}_{\mathrm{CO}} / \mathrm{VA}\right)$, carbon monoxide transfer coefficient (diffusing capacity for carbon monoxide adjusted for alveolar ventilation) (carbon monoxide transfer coefficient is approximately $\mathrm{K}_{\mathrm{CO}} /$ barometric pressure in $\mathrm{ml} / \mathrm{min} / \mathrm{mmHg} / \mathrm{l}$ ); VA, alveolar volume; pre values, before bronchodilation; post values, post bronchodilation; SD, standard deviation.

Environmental $\mathrm{SiO}_{2}$ measurements. The period when samples were received was the one in which at the tunneling process a spray gun, also known as GUNITE was extensively used; GUNITE contains $\mathrm{Na}_{2} \mathrm{SiO}_{3}$ and was present at all the working positions. Moreover, splashed concrete contains components such as cement (containing $5 \%$ silica- $\mathrm{SiO}_{2}$ ), additives, aggregates, coagulation accelerators and silica foam. It is often used in tunnels, underground works to stabilize slopes and excavations. Low exposure to respiratory crystalline silica powder was observed among workers in underground excavation and tunneling. In particular, the concentration of $\mathrm{SiO}_{2}$ in underground construction was $0.0125 \mathrm{mg} / \mathrm{m}^{3}$ at all working positions from which samples were drawn (Table I).

PFTs. The results of the PFTs performed are shown in Table II. According to analysis of the results, 51 employees $(61.4 \%)$ were within normal limits, $22(26.5 \%)$ were diagnosed with mild obstructive syndrome, $4(4.7 \%)$ were diagnosed with mild impairment of diffusing capacity and 2 (2.4\%) were diagnosed with moderate restrictive syndrome. However, groups did not differ statistically significantly. The type of working activity (underground-outdoor) was significantly associated with categorization of PFT $(\mathrm{P}=0.038)$. The comparison of underground and outdoor construction workers (Fig. 1) revealed that underground workers were less likely to lie within normal limits compared to those working outdoors (53.8 vs. $64.9 \%$ respectively, $\mathrm{P}=0.038$ ). In Fig. 1, the comparison of the functional respiratory testing results for the various working activities are presented.

Radiology testing. Of the 86 workers, 69 participated in the radiological examination. The remaining 17 employees 
Table III. Radiological findings and type of job.

\begin{tabular}{llcc}
\hline Type of job & No findings & Specific to occupational disease & Non-specific \\
\hline Underground & $16(59.30 \%)$ & $3(11.10 \%)$ & $8(29.6 \%)$ \\
Outdoor & $36(85.7 \%)$ & $2(4.80 \%)$ & $4(9.5 \%)$ \\
\hline
\end{tabular}

Corresponding radiological findings are shown in Fig. 3. In one patient the chest X-ray revealed a suspicious right hilar enlargement, as an incidental finding. A subsequent CT scan of the chest confirmed the presence of a right hilar mass, consistent with lung cancer.

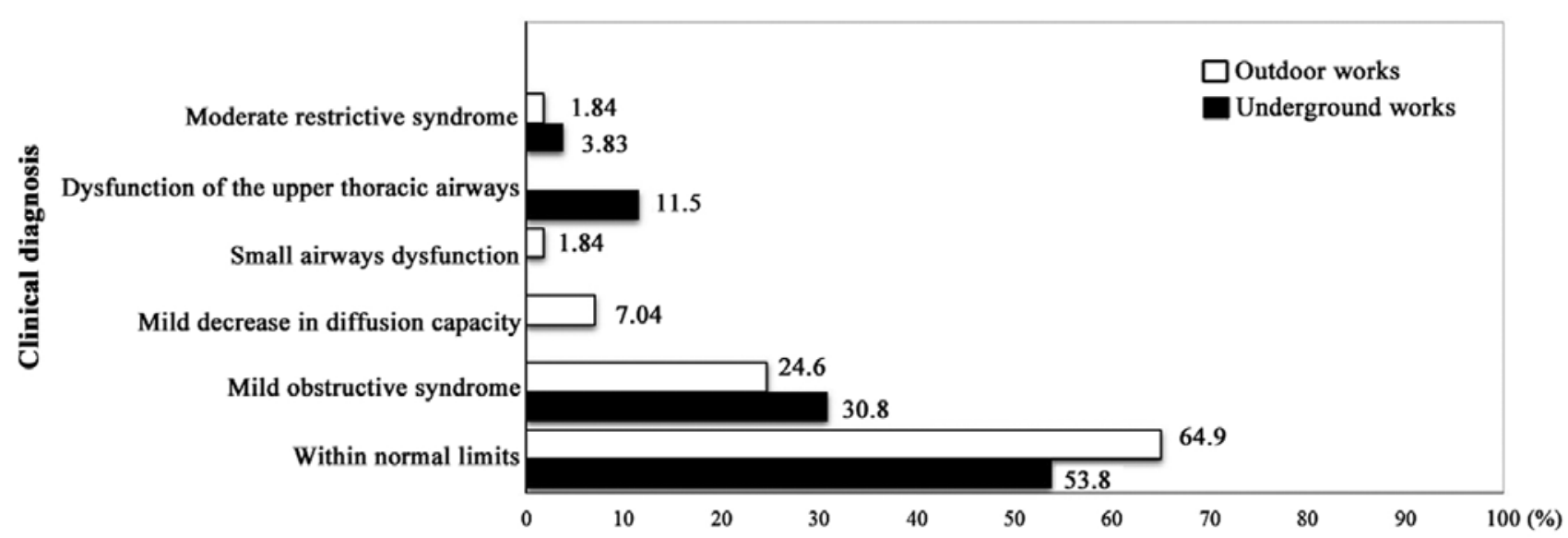

Figure 1. Results of functional respiratory testing for various types of working activity (underground and outdoor construction projects).

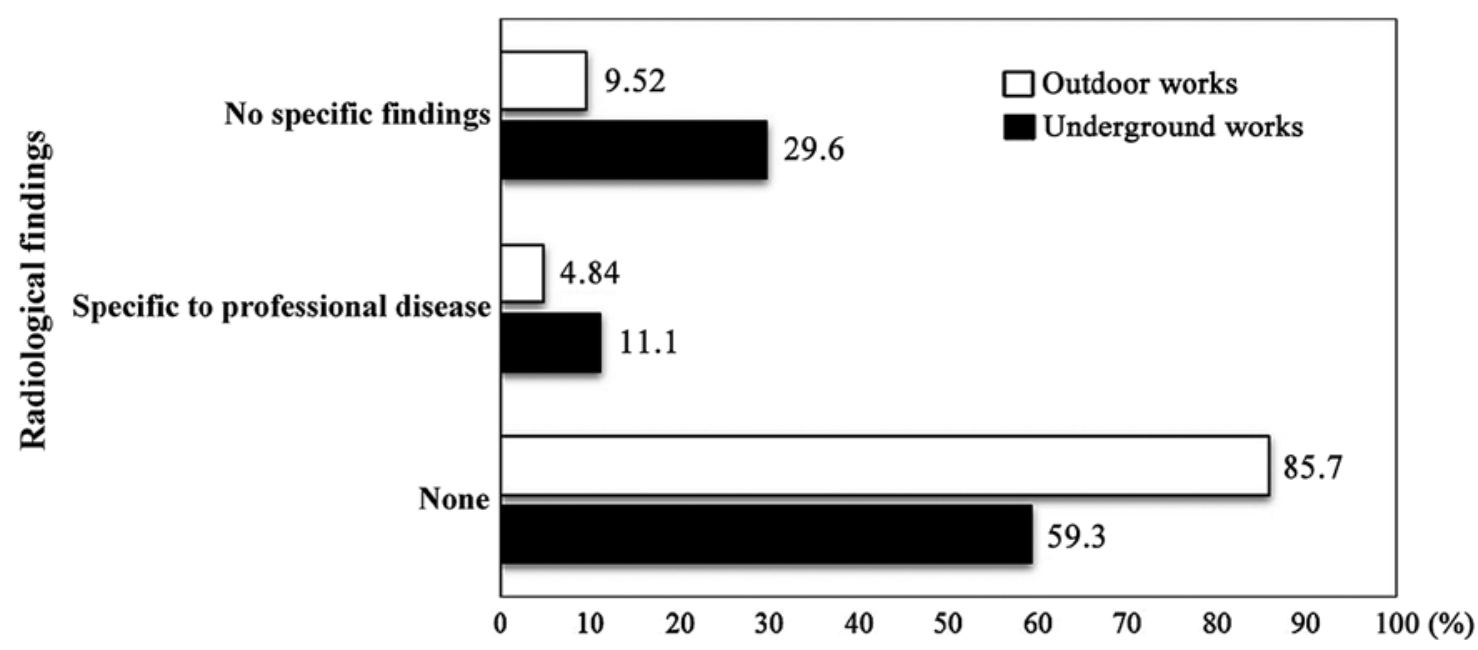

Figure 2. Categorization of radiology findings for the various types of working activity.

from the company engaged in outdoor construction projects, refused to participate in the radiological examination because they stated that they had performed this test at the same year as part of their collaboration with the company. Of the 69 employees, in 52 (75.4\%) no findings were recorded and five $(7.2 \%)$ were diagnosed with specific occupational disease findings, while $12(17.4 \%)$ presented non-specific findings. Then, 1 out of the 5 subjects with abnormal findings in chest X-ray was diagnosed with lung cancer three months later. The comparison of underground and outdoor construction workers (Table III, Fig. 2) showed that underground workers were almost $30 \%$ more prone to develop radiological findings compared to those working outdoors $(\mathrm{P}=0.044)$. Furthermore, underground jobs were more likely to be linked both to specific (11.1\% vs $4.8 \%, \mathrm{P}=0.044)$ and non-specific (29.6 vs. $9.5 \%, \mathrm{P}=0.044$ ) occupational radiological findings compared to outdoor workers. The relationship between job type and categorization of radiological findings was significant (Pearsons $\chi^{2}=6.261, \mathrm{P}=0.044$ ). Corresponding radiological findings are shown in Fig. 3. In one patient the chest X-ray revealed a suspicious right hilar enlargement, as an incidental finding. A subsequent CT scan of the chest 

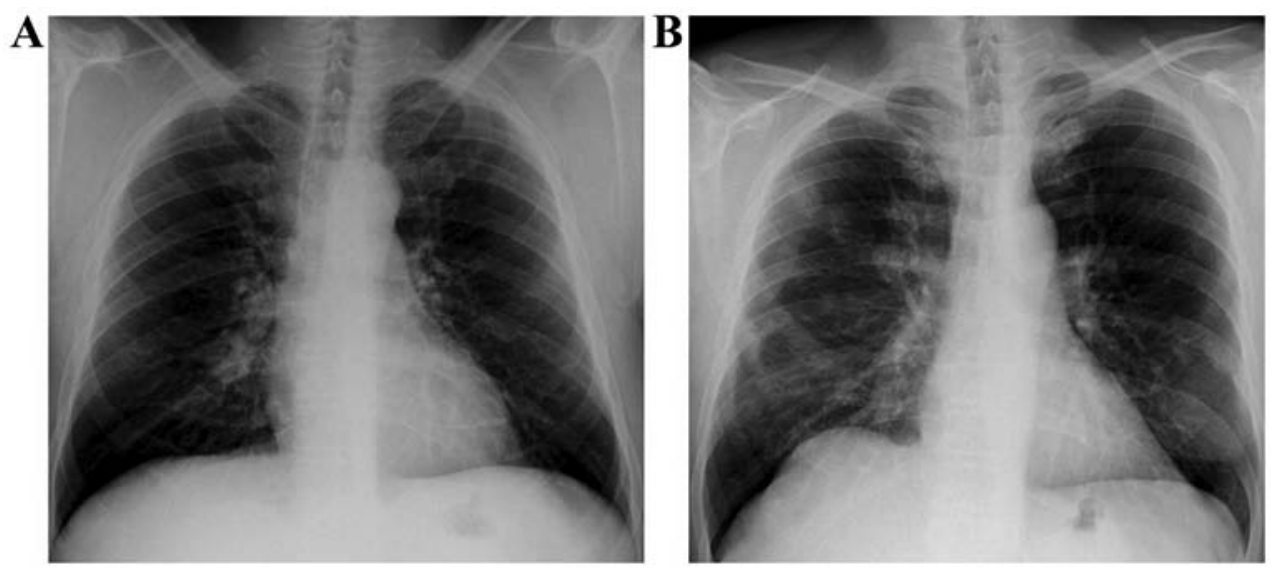

Figure 3. (A) Chest X-ray showing right hilar enlargement. A subsequent CT scan confirmed a right hilar mass due to lung cancer. (B) Chest X-ray showing bilateral calcified pleural plaques and linear opacities in the lower lung zones.

confirmed the presence of a right hilar mass, consistent with lung cancer.

\section{Discussion}

Historically, silicosis is considered as a significant occupational disease and is still of interest (34). During our study, environmental measurements were performed, samples were collected to detect breathable crystalline silica $\left(\mathrm{SiO}_{2}\right)$ in the workplace of outdoor and underground construction works, and medical tests of the PFTs of workers were carried out. Chest X-rays, as well as HRCT were also performed where deemed appropriate in order to obtain a better picture of the diagnosis. Low exposure to respiratory crystalline silica powder was observed among workers in underground excavation and tunneling. In particular, the concentration of $\mathrm{SiO}_{2}$ in underground construction was $0.0125 \mathrm{mg} / \mathrm{m}^{3}$, according to the limit value of $0.1 \mathrm{mg} / \mathrm{m}^{3}$ set by the European Union Directive 2017/2398/L345/87. This limit value is also laid down in the National Mining and quarrying legislation (35). The above concentration of $\mathrm{SiO}_{2}$ in the dust generated in underground construction projects does not make it detrimental to the workers' health in the area (36). According to the study of Leung et al (37) low environmental concentrations rarely pose any risk for silicosis. On the contrary, in the study of Tavakol et al (18) construction workers' exposure to respirable dust of crystalline silica dust exceeded the threshold limit value. A similar conclusion on the exposure limit on respiratory $\mathrm{SiO}_{2}$ in underground excavation works is presented by the study of Mazurek and Attfield (38). An important factor regarding exposure is the production process carried out in underground excavation projects that involves the frequent use of sprayed concrete, also known as GUNITE. Based on the results of the pulmonary function testing in the present study, underground workers were more likely to lie outside the normal limits compared to those working outdoors. In the study by Hochgatterer et al (39), occupational quartz exposure adversely affected lung function parameters. The finding that 5 workers presented occupational disease-specific pathological findings can be considered serious especially since these workers had worked for $>15$ years in underground construction-excavation and tunneling projects. In our study, lung function and X-ray findings did not differ significantly between workers with more than 15 working years against those with less than 15 working years. This is further supported by the establishment of lung cancer diagnosis in one employee three months after the inclusion into the current study. This employee had a 30.5 year working history and was a current smoker (60 packs/year). He mentioned that he was exposed to Sodium silicate $\left(\mathrm{Na}_{2} \mathrm{SiO}_{3}\right)$, sprayed concrete, also known as GUNITE, dust from moving machinery and sand while he also stated that his workplace did not have proper ventilation, while he was wearing personal protective equipment (gloves, masks, helmets, glasses). Since smoking is a risk factor for lung cancer, the employee's lung cancer may be attributed both to environmental working exposure and smoking. According to the study of Kachuri et al (40), exposure of workers for more than 30 years to crystalline $\mathrm{SiO}_{2}$, which is considered a long exposure, is likely to increase the risk of developing lung cancer $(12,40)$. It is worth noting that people working in underground construction projects were fewer in number due to the financial crisis in Greece from 2010 to date. Underground and outdoor projects have been reduced in number throughout the country.

In conclusion, people in the Greek construction industry were not exposed to crystalline silica powder that exceeded the limit value as laid down in the European legislation. Workers in underground tunneling projects with more than 15 years exposure to $\mathrm{SiO}_{2}$ are more likely to develop silicosis in its chronic form (27). Pulmonary function testing revealed that underground workers were less likely to lie within normal limits compared to those working outdoors. As a result, further precautionary measures are required for workers in the construction sector to promote their health and safety. In particular, the following steps are suggested: i) a more frequent training in safe work practices $(41,42)$; ii) the use of appropriate respiratory protection devices in accordance with the requirements of European legislation (43); iii) undertaking of workers to precautionary measures; iv) undergoing of medical tests every year; and v) periodic workplace sampling to perform respiratory crystalline silicon analyses with the results being compulsory reported to the Competent Authority $(36,44)$. Finally, the establishment of a National Occupational Health and Safety System is needed to identify risk factors in the work 
environment in accordance with the National Occupational Health and Safety Strategy (45).

\section{Acknowledgements}

The authors would like to thank all study participants. The authors would also like to thank 'Sotiria' Hospital, both the Department of Imaging and Interventional Radiology, and 1st Department of Pneumonology, Medical School, National and Kapodistrian University of Athens for their evaluation of the study participants and for providing use of the radiology and imaging laboratory. Special thanks for her total contribution to Dr Nektaria Sidiropoulou, Doctor Radiologist.

\section{Funding}

This study was funded by own revenue.

\section{Availability of data and materials}

The datasets used and/or analyzed during the current study are available from the corresponding author on reasonable request.

\section{Authors' contributions}

All authors have read and approved the final version of this manuscript. DK: Organization and performing of research, collecting and testing samples, writing of the research article, overall project management. MA, KT: Evaluation of radiological reports. PB: Evaluation of pulmonary tests. GC: Statistical analysis, data assessment. CT, KT, EC: Statistical analysis and evaluation of the results, preparation, and writing of the research article. IC, VD, AP, EP, TCC, NK, EP, DAS: Reviewing and comprehensive manuscript plan assessment. ACL and PP: Assistance to collecting the necessary samples, in cooperation with DK, data assessment, total preparation and writing of the research article, organizing the references, reviewing and plan assessment.

\section{Ethics approval and consent to participate}

The current study was approved by the Ethics and Bioethics Committee of the Medical School of the National and Kapodistrian University of Athens (Protocol no. 6323 received 6th March, 2013. All procedures were in accordance with the ethical standards of the responsible committee on human experimentation and patient's evaluation reports (institutional and national) and in agreement with the Helsinki Declaration of 1964 and later versions. All the data were original, used in the current study with anonymity and confidentiality. Informed consent or substitute for it was obtained from all study participants-workers prior to enrolment.

\section{Patient consent for publication}

All study participants were informed in detail and agreed to the publication of associated data (and any accompanying images or reports) as appropriate, fully respecting their anonymity and medical ethics. The worker's consent forms from the current study are available from the corresponding author, on reasonable request.

\section{Competing interests}

DAS is the Editor-in-Chief for the journal, but had no personal involvement in the reviewing process, or any influence in terms of adjudicating on the final decision, for this article. The other authors declare that they have no competing interests.

\section{References}

1. NEPSI The European Network on Silica: Agreement on Workers Health Protection through the Good Handling and Use of Crystalline Silica and Products containing it. https://www.nepsi. eu/sites/nepsi.eu/files/content/editor/agreement_-_english.pdf. Updated December 18, 2017.

2. European Commission: Guidance for National Labour Inspectors on addressing risks from worker exposure to respirable crystalline silica (RCS) on construction sites. https://osha.europa. eu/en/guidance-national-labour-inspectors-on-addressing-risksfrom-worker-exposure-to-respirable-crystalline-silica. Accessed October 2016.

3. Apatsidou M, Konstantopoulou I, Foufa E, Tsarouhas K, Papalexis P, Rezaee R, Spandidos DA, Kouretas D and Tsitsimpikou C: Safe use of chemicals by professional users and health care specialists. Biomed Rep 8: 160-165, 2018.

4. Fenga $C$, Gangemi $S$, Giambò F, Tsitsimpikou $C$, Golokhvast $K$, Tsatsakis A and Costa C: Low-dose occupational exposure to benzene and signal transduction pathways involved in the regulation of cellular response to oxidative stress. Life Sci 147: 67-70, 2016.

5. Koulaouzidou EA, Roussou K, Sidiropoulos K, Nikolaidis A, Kolokuris I, Tsakalof A, Tsitsimpikou C and Kouretas D: Investigation of the chemical profile and cytotoxicity evaluation of organic components eluted from pit and fissure sealants. Food Chem Toxicol 120: 536-543, 2018.

6. Sauvé JF, Beaudry C, Bégin D, Dion C, Gérin M and Lavoué J: Silica exposure during construction activities: statistical modeling of task-based measurements from the literature. Ann Occup Hyg 57: 432-443, 2013.

7. Steenland K and Ward E: Silica: A lung carcinogen. CA Cancer J Clin 64: 63-69, 2014.

8. No authors listed: IARC Working Group on the Evaluation of Carcinogenic Risks to Humans: IARC Working Group on the Evaluation of Carcinogenic Risks to Humans: Silica, Some Silicates, Coal Dust and Para-Aramid Fibrils. Lyon, 15-22 October 1996. IARC Monogr Eval Carcinog Risks Hum 68: 1-475, 1997.

9. European Commission: Proposal for a Directive of The European Parliament and of The Council amending directive 2004/37/EC on the protection of workers from the risks related to exposure to carcinogens or mutagens at work. https://eur-lex.europa.eu/legalcontent/EN/TXT/?uri=CELEX\%3A52016PC0248. Accessed May 13, 2016.

10. European Comission: Commission Recommendation of 19 September 2003 concerning the European schedule of occupational diseases (Text with EEA relevance) (notified under document number C(2003) 3297). https://eur-lex.europa.eu/legalcontent/EN/ALL/?uri=CELEX\%3A32003H0670. Accessed September 19, 2003.

11. Hellenic Republic Presidential: Decree no. 41/2012, National list of occupational diseases, in accordance with Commission Recommendation 2003/670/EC 19.09.2003.

12. Rees D and Murray J: Silica, silicosis and tuberculosis. Int J Tuberc Lung Dis 11: 474-484, 2007.

13. Arndt V, Rothenbacher D, Daniel U, Zschenderlein B, Schuberth S and Brenner H: All-cause and cause specific mortality in a cohort of 20,000 construction workers; results from a 10 year follow up. Occup Environ Med 61: 419-425, 2004.

14. Beaudry C, Lavoué J, Sauvé J-F, Bégin D, Senhaji Rhazi M, Perrault G, Dion C and Gérin M: Occupational exposure to silica in construction workers: A literature-based exposure database. J Occup Environ Hyg 10: 71-77, 2013.

15. Oliver LC, Miracle-McMahill H, Littman AB, Oakes JM and Gaita RR Jr: Respiratory symptoms and lung function in workers in heavy and highway construction: A cross-sectional study. Am J Ind Med 40: 73-86, 2001. 
16. Arcangeli G, Cupelli V, Montalti M, Pristera M, Baldasseroni A and Giuliano G: Respiratory risks in tunnel construction workers. Int J Immunopathol Pharmacol 17 (Suppl): 91-96, 2004.

17. Ellingsen DG, Ulvestad B, Bakke B, Seljeflot I, Barregard L and Thomassen Y: Serum pneumoproteins in tunnel construction workers. Int Arch Occup Environ Health 88: 943-951, 2015.

18. Tavakol E, Azari M, Zendehdel R, Salehpour S, Khodakrim S, Nikoo S and Saranjam B: Risk Evaluation of Construction Workers' Exposure to Silica Dust and the Possible Lung Function Impairments. Tanaffos 16: 295-303, 2017.

19. Khoza NN, Grové T and Schutte PC: Worker exposure to silica dust in South African non-mining industries in Gauteng: An exploratory study. Occup Health S Africa 18: 18-26, 2012.

20. Hellenic Pulmonary Society: Occupational and environmental lung diseases. Hellenic Pulmonary Society, Athens, 2007. http:// www.hts.org.gr/assets/files/biblia_epe/epaggelmatika_nosimata. pdf.

21. Hellenic Republic Joint Ministerial Decision: F.80000/45219/1864/2017 Single Disability Identification Table.

22. IARC monographs: Arsenic, metals, fibres, and dusts. Volume $100 \mathrm{C}$. A review of human carcinogens. I ARC, Lyon, 2012. https://monographs.iarc. fr/wp-content/uploads/2018/06/mono100C.pdf.

23. Linch KD: Respirable concrete dust - silicosis hazard in the construction industry. Appl Occup Environ Hyg 17: 209-221, 2002.

24. Tavakol E, Azari MR, Salehpour S and Khodakarim S: Determination of Construction Workers' Exposure to Respirable Crystalline Silica and Respirable Dust. J Saf Promot Inj Prev 3: 263-270, 2016

25. European Commission: Regulation (EC) No. 1272/2008 of the European Parliament and of the Council of 16 December 2008 on classification, labelling and packaging of substances and mixtures, amending and repealing Directives 67/548/EEC and 1999/45/EC, and amending Regulation (EC) No. 1907/2006. https://eur-lex.europa.eu/eli/reg/2008/1272/oj. Accessed December 31, 2008

26. Hellenic Republic Presidential: Decree 77/1993, For the protection of workers against physical, chemical and biological agents and amending and supplementing Presidential Decree $307 / 86$ in accordance with its Directive Council Regulation 88/642/EEC

27. Patakas D: Epithelial pulmonology. 2nd edition. University Studio Press, Thessaloniki, 2006.

28. Macintyre N,Crapo RO, Viegi G, Johnson DC, van der Grinten CP, Brusasco V, Burgos F, Casaburi R, Coates A, Enright P, et al: Standardisation of the single-breath determination of carbon monoxide uptake in the lung. Eur Respir J 26: 720-735, 2005

29. Miller MR, Hankinson J, Brusasco V, Burgos F, Casaburi R, Coates A, Crapo R, Enright $\mathrm{P}$, van der Grinten CP, Gustafsson P, et al; ATS/ERS Task Force: Standardisation of spirometry. Eur Respir J 26: 319-338, 2005.

30. Pellegrino R, Viegi G, Brusasco V, Crapo RO, Burgos F, Casaburi R, Coates A, van der Grinten CP, Gustafsson P, Hankinson $\mathrm{J}$, et al: Interpretative strategies for lung function tests. Eur Respir J 26: 948-968, 2005.

31. Kreider ME and Grippi MA: Impact of the new ATS/ERS pulmonary function test interpretation guidelines. Respir Med 101: 2336-2342, 2007.

32. Webb WR and Higgins CB: Thoracic imaging: pulmonary and cardiovascular radiology. 3rd edition. LWW, 2017.
33. Cox CW and Lynch DA: Medical imaging in occupational and environmental lung disease. Curr Opin Pulm Med 21: 163-170, 2015.

34. Greenberg MI, Waksman J and Curtis J: Silicosis: A review. Dis Mon 53: 394-416, 2007.

35. Hellenic Republic: Ministerial Decision $\Delta 7 / \mathrm{A} / \mathrm{off} .12050 /$ 2223/2011 'Mining and Quarry Works Regulation', Government Gazette, Series II, No. 1227/2011.

36. European Comission: Directive (EU) 2017/2398 of the European Parliament and of the Council of 12 December 2017 amending Directive 2004/37/EC on the protection of workers from the risks related to exposure to carcinogens or mutagens at work. https://eur-lex.europa.eu/eli/dir/2017/2398/oj. Accessed December 27, 2017.

37. Leung CC, Yu ITS and Chen W: Silicosis. Lancet 379: 2008-2018, 2012.

38. Mazurek JM and Attfield MD: Silicosis mortality among young adults in the United States, 1968-2004. Am J Ind Med 51: $568-578,2008$

39. Hochgatterer K, Moshammer H and Haluza D: Dust is in the air: Effects of occupational exposure to mineral dust on lung function in a 9-year study. Lung 191: 257-263, 2013.

40. Kachuri L, Villeneuve PJ, Parent M-É, Johnson KC and Harris SA; Canadian Cancer Registries Epidemiology Group: Occupational exposure to crystalline silica and the risk of lung cancer in Canadian men. Int J Cancer 135: 138-148, 2014.

41. European Commission: Council Directive 89/391/EEC of 12 June 1989 on the introduction of measures to encourage improvements in the safety and health of workers at work. https://eur-lex.europa. eu/legal-content/EN/ALL/?uri=CELEX\%3A31989L0391. Accessed June 29, 1989.

42. Hellenic Parliament: Law No. 3850 of 2010 ratifying the Code of Laws related to Occupational Safety and Health.

43. European Commission: Regulation (EU) 2016/425 of the European Parliament and of the Council of 9 March 2016 on personal protective equipment and repealing Council Directive 89/686/EEC. https://eur-lex.europa.eu/legalcontent/EN/TXT/?uri=CELEX\%3A32016R0425. Accessed March 31, 2016.

44. European Commission: Consolidated text: Directive 2004/37/EC of the European Parliament and of the Council of 29 April 2004 on the protection of workers from the risks related to exposure to carcinogens or mutagens at work (Sixth individual Directive within the meaning of Article 16(1) of Council Directive 89/391/EEC) (codified version). https://eur-lex.europa.eu/legalcontent/en/TXT/?uri=CELEX\%3A02004L0037-20140325. Accessed April 30, 2004.

45. Hellenic Republic Ministerial: Decision no. 48416/2564/2017 Adoption of National Strategy for Health and Safety at Work for the years 2016-2020, 2017.

This work is licensed under a Creative Commons Attribution-NonCommercial-NoDerivatives 4.0 International (CC BY-NC-ND 4.0) License. 